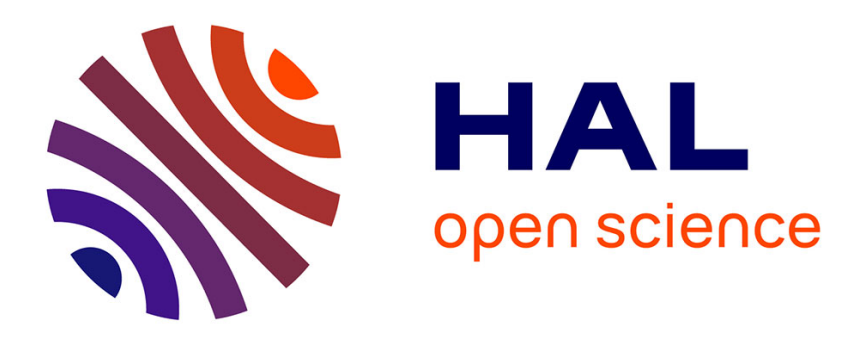

\title{
Negotiating Land Policies to Territorialise State Power Sina Schlimmer
}

\section{To cite this version:}

Sina Schlimmer. Negotiating Land Policies to Territorialise State Power. Revue internationale des études du développement, 2019, 238, pp.33-59. 10.3917/ried.238.0033 . halshs-02418099

\section{HAL Id: halshs-02418099 https://shs.hal.science/halshs-02418099}

Submitted on 18 Dec 2019

HAL is a multi-disciplinary open access archive for the deposit and dissemination of scientific research documents, whether they are published or not. The documents may come from teaching and research institutions in France or abroad, or from public or private research centers.
L'archive ouverte pluridisciplinaire HAL, est destinée au dépôt et à la diffusion de documents scientifiques de niveau recherche, publiés ou non, émanant des établissements d'enseignement et de recherche français ou étrangers, des laboratoires publics ou privés. 


\title{
NEGOTIATING LAND POLICIES TO TERRITORIALISE STATE POWER
}

\section{The Political Outcomes of Land Deals in Tanzania}

\author{
Sina Schlimmer
}

Éditions de la Sorbonne | «Revue internationale des études du développement » 2019/2 N²38 | pages 33 à 59

ISSN 2554-3415

ISBN 9791035103200

Article disponible en ligne à l'adresse :

https://www.cairn.info/revue-internationale-des-etudes-dudeveloppement-2019-2-page-33.htm

Distribution électronique Cairn.info pour Éditions de la Sorbonne.

(C) Éditions de la Sorbonne. Tous droits réservés pour tous pays.

La reproduction ou représentation de cet article, notamment par photocopie, n'est autorisée que dans les limites des conditions générales d'utilisation du site ou, le cas échéant, des conditions générales de la licence souscrite par votre établissement. Toute autre reproduction ou représentation, en tout ou partie, sous quelque forme et de quelque manière que ce soit, est interdite sauf accord préalable et écrit de l'éditeur, en dehors des cas prévus par la législation en vigueur en France. Il est précisé que son stockage dans une base de données est également interdit. 


\title{
Negotiating Land Policies to Territorialise State Power
}

\section{The Political Outcomes of Land Deals in Tanzania}

\section{Sina Schlimmer}

\section{KEYWORDS}

land deals, policy analysis, state-building, post-socialism, Tanzania

\begin{abstract}
Land policies have been shaping the (trans)formation of the Tanzanian state since independence. Nevertheless, Tanzania has been referred to as a target country of the international "land rush," which is often associated with a declining role of state actors in the land sector. This article argues, on the contrary, that the negotiations of land deals since the end of the 2000s have reconfirmed an interdependent relationship between land policy processes and state-building. While the formulation of investment-promoting land policies since the 1990s suggests that the privatisation of the sector has increased the leeway for foreign investors, their implementation has reaffirmed the omnipresence of state power. More broadly, the theoretical aim of this article is to consider large-scale land deals as a heuristic object for studies in political science investigating state (trans)formation in Africa.
\end{abstract}




\section{Introduction}

Tn November 2016, the Tanzanian government issued a draft National L Land Policy, which-according to initial media reports-predicted "tough conditions for foreigners eyeing land for business in Tanzania” (Materu, 2016). ${ }^{1}$ The regulations were conceived, inter alia, as a response to shady land deals with international companies, which have been fuelling the political debate in the country for more than a decade (Kubegeya, 2015; Kitabu, 2013; Lugungulo, 2010). Tanzania has often been considered as the target of a rush on arable land by international investors, which has led to lively discussions among activists, experts, and scholars the world over (Locher, 2017; The Oakland Institute, 2011; Sulle and Nelson, 2009).

More than ten years after the launch of initial media and research reports addressing the increasing number of large-scale land deals (LSLD) in so-called developing countries, the commodification and transaction of land rights still remain a central topic, not only on the international development agenda, but also within the scientific community. Scholars have tried to identify the driving forces behind the global land rush and to apprehend the impacts of land alienation on socioeconomic dynamics and land tenure systems (Kenney-Lazar, 2012; Smalley and Corbera 2012). This accumulation of case studies has led to the constitution of a pluri-disciplinary scientific field providing information about the global land grab "hype" (Kaag and Zoomers, 2014). By identifying the stakeholders, processes, and outcomes involved in LSLDs, the literature sometimes limits its scope to explaining this fashionable research object in itself. Most authors have resorted to different theoretical frameworks and analytical approaches in order to explain the phenomenon, rather than taking LSLDs as a focal point for disciplinary debates. This article uses land transactions as an original research object in political science and, more particularly, as a starting point for studying state-building processes in Africa. The argumentation is based on the observation made in previous studies that states are key players in the negotiation of ISLDs (Moreda, 2017; Lavers and Boamah, 2016; Evers et al., 2013; Wolford et al., 2013). Unlike some ideas spread by initial media reports, academic research has shown

1 The research for this article was funded by research grants from the French Ministry of Higher Education and Research and the French Institute for Research in Africa based in Nairobi. The author expresses her gratitude to the reviewers for their insightful and constructive comments. 
that land is not just grabbed arbitrarily by wealthy investors. Instead, what transpires is that public and political stakeholders play a pivotal role in land deals, mostly through policy-making and by interacting directly with private stakeholders (investment companies, local community members, NGOs, etc.). This article is based on the assumption that the negotiation of land reforms and state-building are mutually dependent (Boone, 2007; Schlimmer, 2017). Using the Tanzanian experience as a case study, the aim of the argumentation is twofold: firstly, the results demonstrate that land investment policies are constantly (re)negotiated by state agents on different administrative levels (politics makes policies). Secondly, it is argued that a critical analysis of the formulation and implementation of recent land investment policies provides information about the historical trajectory of the Tanzanian state (Bayart, 1989) in more general terms (policies make politics). Thus, the article contributes to this special issue both by studying a "state at work" (Bierschenk and Olivier de Sardan, 2014) in the negotiation of land deals and by situating LSLDs in a broader discussion on the (trans) formation of African states.

Most studies dealing with the role of the state in the negotiation of recent land deals have underlined the favourable position of host states "creating the fertile ground for foreign investment" (Evers et al., 2013, p. 5). National and local decision-makers may pave the way for land acquisitions, by adopting investment-friendly policies and by creating alliances with foreign investors (Hall et al., 2015; Cotula, 2013; Dabat, 2011). However, this paper argues that the reactions of "host states"-considered as a heterogeneous set of actors, practices, representations, and symbols-to the growing interest in farmland investment are often more diverse (Boone, 2014; Lund and Boone, 2013; Wolford et al., 2013). The article aims to contribute to research, which analyses the link between ISLDs and state-building, by focusing on the complexity, contradictions, and overlapping interests within the state machinery (Hagmann and Péclard, 2010; Migdal and Schlichte, 2005), which sometimes reorient, circumvent, retard, or even block the implementation of land transactions. Public policy analysis provides heuristic approaches to unpack the state's black box and to scrutinise the diverse dynamics at work (Darbon and Provini, 2018). Its tools are useful, not only to disentangle the processes and sequences of land investment policies, but also to capture the relationships and interactions between various (private, public, 
hybrid, etc.) stakeholders (Hassenteufel, 2014). By focussing on the making and implementation (Hill and Hupe, 2014) of land investment policies, the aim is to uncover the complexity of political reactions, which tend to be masked by reductive terms such as "land grabbing" or "investment project" (Schlimmer, 2018a).

However, the strategic intervention of state agents in the land sector is not a recent phenomenon. Previous studies have shown that policies regulating access to and distribution of land have helped to expand political power, thereby shaping the nature of the Tanzanian state, throughout colonial and postcolonial history (Bjerk, 2015; Abrahams, 1985; Coulson, 1982). Between the 1960 and the 1980 s in Tanzania, land administration tools were crucial to building a socialist state based on rigorously planned villages. After the end of the ujamaa era, heralding a policy shift towards a more liberal agenda, the Tanzanian government adopted a set of programmes, tools, and institutions promoting farmland investment and the commodification of land rights. These initiatives are often interpreted as a transition of the state towards a neoliberal era (Cooksey and Kelsall, 2011; Harrison, 2010), leaving behind the legacy of more than 20 years of socialist government and paving the way for large-scale land investment by international companies and "land grabbing" (Part 1). The patterns of implementation of these pro-investment policies through land deals since the 2ooos, however, paints a more complex picture of the land sector (Pedersen, 2012). State agents at different administrative levels use the opportunities created during the negotiation of land deals to reassert their authority over land and to extend their territorial control (Peluso and Lund, 2011; Igoe and Brockington, 2007). These territorialised policy processes are shown in this paper through the results of two case studies, located in the Coast and Iringa regions. Both land investment projects were shaped by negotiations in which political and administrative stakeholders struggled over the control of land, thereby creating "pockets of stateness" (Part 2). Given these seemingly contradictory results, this paper argues that an approach based on policy analysis helps to reflect the different periods, ideologies, practices, and processes of public action, shaping the complex nature and the historical (trans)formation of the Tanzanian state.

This research is based on a Ph.D. dissertation in political science. Several theoretical and methodological tools are used for studying state action at 
different moments of the policy process. The first part of the article discusses the historical trajectory of the Tanzanian state through the lens of land policy formulation. Second-hand data such as academic literature and official policy documents are used to discuss the link between state (trans)formation and land reform since independence. The second part of the study analyses contemporary forms of state territorialisation through the implementation of land policies. This approach is based on primary data stemming from empirical field work, which was carried out mainly from April to June 2014 and April to September 2015. The case studies were conducted on three specific land deals with foreign companies (the Swedish based company Agro EcoEnergy in the Bagamoyo District, the British based companies Sun Biofuels in the Kisarawe District and New Forest Company in the Kilolo District). They draw upon documentary research, semi-structured interviews with multiple stakeholders (representatives of the company, administrative staff, and members of parliament), as well as a press review covering the period between 2000 and 2015 .

\section{State-Building and Land Policies in the Postcolonial Era: Towards a Neoliberal Regime?}

In 2013, the research group Land Matrix defined Tanzania as one of the most common targets (Anseeuw et al., 2013) of international interest in farmland. Its amenable political and economic climate was considered as one of the main factors driving international investors towards the East African country (Locher, 2015). However, it is not necessarily evident that the Tanzanian land sector is an environment where plots of land and access rights can be traded freely. Before getting involved in investment-promoting and neoliberal-inspired land policy-making at the beginning of the 1990s, Tanzanian leaders were busy developing and constructing a socialist state. In fact, land policies were crucial in establishing a post-independence state. Reviewing the historical trajectory of land policies is essential, not only for a better understanding of the specific meaning of "land grabbing" in Tanzania, but also to stress the intersections between land management and state formation, which have multiplied since independence. ${ }^{2}$ The aim

2 Land policies were also a tool for state-building under British colonial rule. However, this period is outside the scope of this article. 
of the following sections is to demonstrate how the land policies that were adopted by the successive postcolonial governments reflect the historical trajectory as well as the changing nature of the postcolonial state.

\subsection{Post-Independence Land Policies as a Tool to Build a Socialist State}

When Julius K. Nyerere ran the Independence movement of his party TANU (Tanganyika African National Movement) at the end of the 1950s, the land question quickly emerged as one of the priority issues in his speeches about an independent nation. Nyerere, who later became the Republic of Tanzania's first President, had clear ideas and principles regarding the design of a post-independence land tenure system and its role in the constitution of a post-colonial and socialist state. Unlike his counterparts in neighbouring countries such as Kenya, Nyerere strictly refused the liberal concept of individual land rights through the introduction of freehold land tenure, as had been suggested by the colonial administration. During a speech made in 1958 about the right to own property (Mali ya taifa), Nyerere strongly opposed the idea of a liberalised land tenure system, based on individual property rights, which would facilitate land transactions and commodification (Kamata, 2010). The rejection of private land property by the TANU leader became one of the markers and symbols of the postcolonial political regime. He saw private property as an imported capitalist concept, which was incompatible with the existing traditional and communal land tenure system:

The foreigner introduced a completely different concept-the concept of land as a marketable commodity [...] we must reject also the capitalist methods which go with it. One of these is the individual ownership of land. To us in Africa land was always recognised as belonging to the community. (Nyerere, 1968, p. $7-8)$

Nyerere's refusal of a liberalised market based on privately-owned land was closely linked to his fear of economic domination by foreign stakeholders. For him, the process of building a unified, independent nation went hand in hand with the creation of a self-sufficient economy. The introduction of a freehold land tenure system would encourage external economic powers to continue controlling the country's natural resources to the detriment of Tanzanian citizens. In his $195^{8}$ speech, he warned that 
it will not be difficult to predict who, in fifty years' time, will be the landlords and who the tenants. In a country such as this, where, generally speaking, the Africans are poor and the foreigners are rich, it is quite possible that, within eighty or a hundred years, if the poor African were allowed to sell his land, all the land in Tanganyika would belong to wealthy immigrants, and the local people would be tenants. (Nyerere, 1966, p. 55-56)

For Nyerere, Tanzanians were the only legitimate land owners. This rejection of foreign land acquisitions and the promotion of land ownership based on citizenship were key elements of nation-building in Tanzania (Schlimmer, 2018b; Aminzade, 2013).

Drawing on anti-capitalist ideology, the first post-independence government designed a land administration system controlled by state agents, especially from the central level. As land ownership was considered to be a right exclusive to Tanzanian citizens, the central government presented itself as the guarantor of equal access to land. In the late 1960s, land allocation systems based on customary tenure were definitively abolished ${ }^{\mathbf{3}}$ and the president was empowered to revoke rights of occupancy in the name of public interest (United Republic of Tanzania, 1967). This legislation, favouring centralised land control, laid the groundwork for Nyerere's large-scale social engineering project of building an independent state, based on meticulously planned rural settlements, better known as the villagisation programme. In fact, the relocation and reorganisation of groups of people in rural Tanzania represented a cornerstone of Mvalimu's ${ }^{4}$ plan to build a socialist society on a collectively organised and strictly controlled basis (Scott, 1998). The vijiji operation (1967-1975), a key element of Nyerere's ujamaa ${ }^{\mathbf{5}}$ programme, was based on the assumption that villages are catalysts of economic development (Friis-Hansen, 1987). Entire communities had to be relocated into artificially created and carefully planned ujamaa villages, considered as communal and cooperative entities, "in which people would live together and work together

3 In certain parts of the country, semi-feudal land tenure systems continued to exist, such as the Nyarubajna regime, but they were definitively abolished by the Customary Leasehold (Enfranchisement) Act of 1969.

4 Mwalimu means "teacher" in Swahili. It symbolises Nyerere's fundamental values and principles, as well as his role as father of the nation.

5 J. K. Nyerere translates the Swahili word ujamaa by "familyhood." In the Arusha Declaration of 1967, Nyerere promoted the idea of African socialism aiming to equally redistribute the country's resources among the population. 
for the good of all” (Boesen et al., 1977, p. 14). Deconcentrated state agents implemented strict rules defined by central government authorities regarding land allocation and imposed specific types of land uses. Existing land claims and agricultural practices were swept aside in order to create an allegedly free basis to establish a new mode of social and political organisation (Lal, 2015; McHenry, 1979; Hyden, 1975; Fimbo, 1974).

These villagisation policies had different socio-economic impacts across the country and their outcomes differed from one region to another. However, the reinvention of rural society, through which several million rural residents were relocated to around 8,ooo ujamaa villages, involved setting up a multilayered state machinery implementing and supervising the project. The villagisation programme is a prime example of the interdependence between state formation and land policy processes. The postcolonial government did not only seek to extend its reach over the "uncaptured peasantry" (Hyden, 1980) by taking control of land allocation and by transforming socio-economic activities into fixed standardised practices. The design of a rural society based on socialist principles and a strictly state-controlled access to land built a symbolic barrier against the idea of liberal and capitalist land markets that were shaping some of Tanzania's newly independent neighbouring states such as Kenya (Manji, 2012, Klopp, 200o). Only at the end of the 1980s, when Nyerere stepped down from the presidency, leaving behind the fragments of the failed ujamaa enterprise, did decision-makers in the land sector start to embrace the concepts and vocabulary that shaped land rights as a marketable commodity.

\subsection{Land Reform in a Post-Socialist State: A Shift in Policy Formulation Towards the Promotion of Private Investment in Land}

The end of the Nyerere era, and with it the decay of villagisation, ushered in a phase of land reform, confronting different views on the reconfiguration of the land tenure system (Schlimmer, 2017; Sundet, 2004; Manji, 1998). Arbitrary land expropriations and reallocations carried out during ujamaa on an unclear legal basis provoked conflicting land claims and raised the question of the proper management of the land tenure system. At the end of the 1980s, in the context of an intensifying economic crisis, the government reopened the debate with international organisations which 
strongly promoted structural adjustment programmes and the country's transition towards a free-market system. Their recommendations regarding land reform were based on a liberal dogma that considers individual land rights as a key to private market mechanisms and economic development. The Tanzanian government embraced these ideas and principles, which were enshrined in several pieces of legislation. The National Agricultural Policy of 1983, for instance, triggered a growing demand for farmland by removing the existing restrictions on land acquisition by private investors. Stakeholder meetings preparing the National Land Policy of 1995, followed by the adoption of the Land Acts of 1999, were driven by the argument that formalised and clearly determined land rights contribute to a fertile and suitable environment for (international) private investment. ${ }^{6}$ The adoption of the new land legislation was followed by several programmes of land registration and investment promotion, which endorsed liberal principles regarding land management.

This shift within the policy agenda gave rise to the establishment of several institutions meant to create fertile ground for investment activities. In 1997, the government adopted the Tanzanian Investment Act, which was followed by the creation of the Tanzania Investment Centre (TIC), designed as "the Primary Agency of the Government to coordinate, encourage, promote and facilitate investment in Tanzania and to advise the Government on investment policy and related matters" (TIC, 2017). The TIC was conceived as an interface between central government and the private sector to facilitate investment projects in specific sectors. It was to serve as a "one-stop shop" (Cotula et al., 2009), where foreign investors meet the representatives of the different state agencies they have to deal with in order to implement their business project (Ministry of Lands, Ministry of Agriculture, Ministry of Finance, Immigration Service, etc.). In 2005, the government announced its intention to establish a land bank containing land plots suitable for investment and

6 The land reform process of the 1990s was shaped by an opposition between, on the one hand, a commission inquiring into land matters convened by President Ali H. Mwinyi and led by Issa G. Shivji, a critic of capitalism, and on the other hand, a secretly formed expert group within the Ministry of Lands. Whereas the "Shivji Commission" advocated for the decentralisation of the land administration and advised restricting the allocation of land to non-Tanzanian entrepreneurs, the ministerial report promoted a centralised land management system, as well as foreign private investment. The NLP of 1995 reflects the recommendations of the latter and pays little attention to the Shivji report. 
ready to be transferred to foreign investors (The Guardian, 2005). Through the Land Acts of 1999, all land has been subdivided into three categories: village land (mainly managed and allocated by village authorities), reserved land, and general land (managed by central state authorities). Foreign investors cannot directly acquire village land, but they can obtain a derivative right of occupancy over general land. Therefore, a village land plot must first be transformed into general land. This conversion from village to general land involves a multilevel decision-making process, which may take several years and is often considered to be an obstacle to "smooth" investment activities (Schlimmer, 2016; Locher and Sulle, 2014; Isaksson and Sigte, 2009). The land bank was designed to facilitate LSLDs by pre-identifying and converting available village land, thereby reducing bureaucracy and interactions between administrative and private stakeholders.

During the 2ooos, large-scale land and agricultural investment projects were further promoted by internationally funded policy programmes, such as the Agricultural Sector Development Programme (2006), the Kilimo Kwanza (Swahili for "agriculture first") resolution (2009), the implementation of agricultural investment or "growth" corridors (e.g. the Southern Agricultural Growth Corridor), as well as the Big Results Now initiative (2012). The missions and aims of these different institutions and programmes were all based on the general assumptions that i) fertile farmland in Tanzania is abundant and available and that ii) private investment based on the commodification of land rights "will be necessary in unlocking the potential of Tanzania's land resource” (United Republic of Tanzania, 2013).

This range of investment-promoting policies from the $1990 \mathrm{O}$ and $2000 \mathrm{~s}$ has often been interpreted as a major step in Tanzania's transition from a socialist regime to a liberal, market-led economy. After almost three decades of state-controlled land management and agricultural production, the implementation of donor-funded policies promoting privatisation is generally seen as a decline of the Nyerere era, paving the way for liberalism (Edwards, 2014; Lofchie, 2014). Regarding the land sector, it has been argued that the 1990 o reforms heralded a "neoliberal, pro-investment period" (Boone and Nyeme, 2015), triggering increasing demand for farmland from international investors and land grabbing. However, even if the transition from ujamaa to investment promotion represents a tremendous policy shift, it did not 
affect the interdependence between land reform and state-building. Both the villagisation programme and pro-investment policies shaped the architecture of the state on the one hand, and represented a set of tools for state agents from different periods to territorialise their authority over land on the other. With the increasing promotion of liberal land policies, hybrid forms of stateterritorialisation were observed, especially during the implementation of international land deals, which will be discussed in the next section. Although the formulation of pro-investment land policies since the 1990 os clearly indicates the adoption of a favourable position regarding land alienation by state actors, their implementation offers insights into inter-administrative conflicts and strategies, which can alter and reorient policy outcomes.

\section{2. (Re-)Negotiating Land Deals to Extend the Reach of the State. The Sun Biofuels Limited and New Forest Company Cases}

Recently, "host governments" and state agents were portrayed as key stakeholders in the international land rush. To a large extent, this assumption is founded on the methodological approaches used to apprehend the role of the state in LSLDs. Firstly, much of the land grab literature focussing on Africa has drawn a picture of fragile, inconsistent, or even weak host states. Ambiguous, porous, and pluralistic land tenure systems, corruption and resource-poor institutions are considered as basic features of states favouring externally driven negotiations about the access to land rights (Nolte and Väth, 2015; Häberli and Smith, 2014; Zoomers, 2010). Secondly, the state's role in LSLDs is often reduced to the decisions made by central government actors and political elites promoting land commodification. Based on policy analysis tools, this second section sets up an alternative approach revealing a more complex picture of the relationships between land investment policies and public action. While the formulation of investment-promoting land policies since the 1990 os seems to have created increasing leeway for foreign investors, their implementation has been shaped and renegotiated by various stakeholders at different administrative levels (Pedersen, 2016). Thus, the large-scale agricultural projects of the so-called "neoliberal era" are still an integral part of state-building, as they were during the colonial and postcolonial eras (Scott, 1999; Bates, 1981). The cases of two land deals located in the Pwani and Iringa regions underline how state agents use land deals as 
tools to enforce political authority over territory and people (Moreda, 2017). Thus, even in the context of privatisation and with the increasing influence of international stakeholders, land policies continue to be used to redefine and exercise state power.

\subsection{The Sun Biofuels Jatropha Project in the Kisarawe District: A "Failed" Large-Scale Land Deal Caught Between Transnational Mobilisation and Inter-Administrative Struggles}

When the British-based company Sun Biofuels Limited (SBF) signed a Memorandum of Understanding (MoU) with the representatives of the Kisarawe District Council (KDC) in September 2005, the investors were driven by big ambitions, aiming to "become one of the biggest producers of biofuel in the world" (Sun Biofuels, 2006). The company intended to acquire 18 ,ooo hectares of farmland in an area close to Dar es Salaam to establish a large-scale jatropha plantation, providing 5,ooo jobs for local communities. District land agents and university experts conducted a survey in the area identifying 8,211 hectares of available village land across 11 villages, which was transferred to the company in the form of a Granted Right of Occupancy (GRO) in 2009 for a duration of 99 years. However, two years after the official land transfer in 2011, national newspapers announced the bankruptcy of the company, which had not yet even started production (Lugungulo, 2011). The following years were marked by uncertainty about the fate of the project, as well as the possibility of village communities getting their land back. ${ }^{7}$ Whereas NGOs and some politicians advocated for the revocation of the land title and for land redistribution among the initial land owners, the company progressively sold its assets to the British-based company Mtanga Foods Limited (MFL), which started a cattle-rearing project in Kisarawe in 2014.

The land deal with SBF and the resale of the company's shares were managed by central state authorities. In addition, several agents of the KDC (land officers, surveyors, the KDC director, etc.) were involved in the deal and

7 When the SBF project failed, the village land had already been converted into general land, meaning that the village government no longer had the authority to govern land allocation. A derivative right of occupancy had been granted to SBF, which has held the land title up to this day. Previous research has shown that the legal status of land changes through the implementation of projects, even if they fail (Duvail et al., 2010). 
the signature of the MoU from the beginning. They sought to reaffirm their authority during the negotiations with the different companies. Given the accumulation of environmental and economic challenges in Kisarawe (water scarcity, unemployment, poor road infrastructure, etc.), the SBF investment project was seen as a potential source of income and an opportunity for providing services to the people. However, after the company's bankruptcy, local authorities became more sceptical and reconsidered their collaboration with foreign investors.

When MFL acquired the company's shares and introduced 160 heads of cattle at the end of 2013, the district authorities asked MFL to remove the animals from the farm. Since SBF had acquired the land plot for agricultural use, MFL was required to apply for a change of land use and to submit a new investment proposal, which involved the preparation of an environmental and social impact assessment. MFL was able to fulfil the requirement,

but to get there was quite an obstacle and a lot of bureaucratic involvements especially when you get down to the council level, the Kisarawe district council. They really would have done nothing if the company hadn't got [...] the Environmental Impact Assessment Company and organised some meetings [...]. It was very difficult. ${ }^{\mathbf{8}}$

During this new evaluation process, the district agents redesigned and strengthened internal procedures to avoid more allegations of facilitating land grabbing. After the failure of the jatropha project, KDC agents were accused of collaborating with dubious investors that acquired large plots of lands without fulfilling their promises in terms of employment and socioeconomic development (Domasa, 2013; The Guardian, 2013). Increasingly, district agents investigate the feasibility of investment projects and define specific criteria the companies have to fulfil before acquiring land, such as financing Village Land Use Plans (VLUP) targeting village land. According to a KDC land officer, these procedures make it more difficult for investors to acquire land in Kisarawe:

There are few new investors who come because we have added some tasks. We have added that if he [the investor] is committed now [...] he should first

8 Interview with a representative of SBF, Dar es Salaam, 25 June 2015. 
fulfil all the promises to the villagers, at least half of the promises. He should prepare Land Use Plan[s] before he has started the investment. ${ }^{9}$

By promoting and at the same time shaping ISLDs, KDC agents reassert their legitimacy as a district authority with regard to local communities and the central government. However, the case of SBF was not only influenced by internal district negotiations. Its outcomes were also shaped by interadministrative conflicts involving central state, district, and village authorities, as well as the representatives of an international NGO. When SBF withdrew from the deal in 2011, only individual landowners had been compensated by the company. The compensation for communal land, however, had not been paid, although this is a legal condition for obtaining a GRO. The fact that these informal practices disadvantaged several villages was proof enough for national and international media and NGOs to consider the SBF case as a land grab (HakiArdhi, 2013; Liberti, 2013; ActionAid, 2012). The NGO ActionAid Tanzania-a pioneer of advocacy against land grabbing in the country-encouraged members of the eleven villages to form a "task force" to follow up on the absence of compensation. This intervention triggered a reconfiguration of the power play in favour of village communities and the central government. It turned out that several district agents had tried to accelerate the land transfer to SBF illegally, by issuing false documents to the Ministry of Lands confirming the compensation for communal land (The Citizen, 2013). Village and central authorities were thereby circumvented. With financial and technical help from ActionAid Tanzania, the village leaders reported the fraud to the Ministry, which subsequently took control of the negotiations for the land deal. The Ministry called upon the district authorities to deal with the indemnities immediately. The compensation was finally paid by MFL in 2014 and channelled through the KDC.

Even if the balance of power temporarily shifted towards village and central government authorities, district agents continued to shape the negotiations and to use the land deal to expand their administrative reach. In spite of the villagers' discontent, district authorities chose compensation in kind rather than in cash by directly channelling the amount paid to the KDC by the investor into the construction of dispensaries and village

9 Interview with a land officer at KDC, Kisarawe town, 10 June 2015. 
government offices. The KDC also retained 61 million Tanzanian shillings (ca. 30,ooo euros) out of 549 million TSH for compensation, which was used to pay district agents and to buy a district car. However, the SBF case reflects the shifting power play among a heterogeneous set of state agents driven by different, sometimes contradictory interests, which in turn shape land deals.

\subsection{Land Deal Implementation and State Territorialisation. The Case of New Forest Company in the Kilolo District}

State-forming processes at decentralised levels can also be observed in the case of the land deal with the British-based New Forest Company (NFC). In 2005 , this investor started identifying suitable land for a large-scale forestry project within the district of Kilolo, located in central southern Tanzania. The company initially aimed to acquire 30,ooo hectares to develop the Tanzanian arm of its forestry project, ${ }^{10}$ producing pine trees and eucalyptus. The members of the Kilolo District Council (KiDC) welcomed the project, given the potential socio-economic benefits for local communities in terms of employment, education, and infrastructure extension. Created in 2002 from the subdivision of the neighbouring Iringa District, the KiDC was a relatively new authority whose administrative power and territorial reach was yet to be consolidated. One of the driving reasons for the creation of the KiDC was to establish an administrative relay for private companies aiming to invest in the rural lands of the Kilolo area. The land deal with the NFC and the prospect of tax revenues and infrastructure projects therefore presented an attractive opportunity for the KiDC, which was seeking to assert its legitimacy as a local administration and as a provider of social services to the local people. In fact, by paying production and service taxes to the KiDC and by offering different types of social services to the communities of eight target villages, the investor's involvement could be considered as a substitute for the local administration, whose resources were limited. However, this paper argues that the company's activities regarding social service provision and land acquisition were constantly shaped and renegotiated by state agents trying to reassert their local government authority. Despite the limited financial and technical capacities of the KiDC, its agents constantly intervened in the different steps of the land deal and reframed the decisions and actions undertaken by NFC representatives. These hybrid dynamics of state-building

10 The NFC is an international company with other project sites in Uganda and Rwanda. 
and territorialisation are striking during the process of land acquisition by NFC in different villages.

NFC's request to acquire 30,000 hectares in the Kilolo district was followed by a demographic study carried out by the KiDC on the initiative of the Ministry of Lands, as a result of which the company was allowed to acquire 14,00o hectares. ${ }^{11}$ Together with a delegation composed of district land officials and of the Member of Parliament for Kilolo, NFC representatives visited different villages in order to identify suitable village community land. Residents of several villages contested the acquisition of either community or individually-owned land, which again limited the area of available land to about 6,00o hectares located across eight villages. The company's dissatisfaction with the gradual reduction in the amount of forestry land that it could acquire in Kilolo affected the subsequent steps of the land deal, for instance by encouraging it to use illegal procedures in order to purchase additional land. Between 2006 and 2009 and again from 2010 onwards, representatives went back to some of the target villages to negotiate with individual land owners. The company collaborated with village authorities to conclude individual sales agreements, which were approved by the village governments, without going through the due procedures and informing the authorities at the district level (Locher and Müller-Böker, 2014). An NFC representative explained the company's approach:

For the first time, the Kilolo DC [district council] told us [...] there is a 14,0oo hectares' free land, which has not been used for many years. Then we say 'oh, that is good, that is fine, let's go and see that land.' Then, in the reality, that land was not existing. So, when you go to the villages, they say 'No. There is no village land, this is mine' [...]. So, you start negotiating with the communities, one and another. So, it took some long process to negotiate with this one, with the neighbour and with the neighbour until you get a huge land. ${ }^{\mathbf{2}}$

Not only did the investors not involve the district authorities in the second round of land acquisitions, they also exceeded the maximum area of land which they were legally authorised to purchase from one individual village land owner (5o hectares). In Isele, Kisinga, and Makungu villages, 
the company acquired land plots of between 70 and 253 hectares without consulting officials from the KiDC land department. ${ }^{13}$ When the district authorities found out about the illegal negotiations, they did not take action against the company, but seemed to tolerate the situation by approving the additional land acquisitions. They preferred to accept illicit land deals rather than compromise their image as competent agents vis-à-vis the central government and village communities:

Of course, it was difficult. If we had to follow the law, we had to reject them [NFC]. But you see, the New Forest [Company] has directly gone to the village. They negotiated directly to the people. They have already paid the compensation. Now, if you reject, it's like you're making a conflict between the company and the individual. That means the company turns back to the village to require the people who have received the money to turn it back [...]. Although the mistake is $[\ldots]$ to the company [...], we accepted such a situation and we approved the land, which is acquired illegally in order to harmonise a situation. Because, when we asked the New Forest [Company]: "why you did this?" they said: "look here, the Ministry approved 14,0oo hectares. We are now still having 2,000 (by then it was 2,00o hectares). We need to reach to the land, which is already approved by the Ministry. So, it was just our effort to reach to the expected amount of land". ${ }^{4}$

Given this interplay of actors and strategies, one could assume that the company circumvented the KiDC and thereby challenged local state authority. This paper argues instead that the negotiation of the land deal reflects complementary interests. Whereas the NFC pursued its aim of acquiring more land, district agents continued to use the land deal to territorialise their local state power either by requiring social service provision from the company or by mobilising the company's financial resources for specific administrative tasks. Rather than simply approving the additional land acquisitions by the NFC, the KiDC made its decision dependent on whether the company accepted to finance Village Land Use Plans (VLUP) for the targeted villages. According to the Tanzanian land legislation, villages where land is the subject of transactions and is leased must have VLUPs. However, only a few Tanzanian villages have such plans, given the limited financial and

13 Focus group discussions with villagers of Makungu (13 May 2015), Kisinga (16 May 2015), and Isele (28 May 2014).

14 Interview with a land officer at KiDC, op. cit. 
technical resources of the District Councils, which are responsible for their funding and production. ${ }^{15}$ Since the end of the 2ooos, central government has encouraged local governments to involve private stakeholders to provide funding and technical assistance for land use planning. By requesting that the NFC finance VLUPs for villages where the company aimed to finalise land deals, the KiDC not only shaped its image as an active district government able to raise funds for land management tools, it also repositioned itself within the negotiation arena after having been bypassed by the company. The KiDC agents reframed the negotiation process and thereby reaffirmed local state authority.

\section{Conclusion}

Recently, Tanzania has been seen as a target of the international "land rush", which is often associated with a declining role of state actors in the land sector. Whereas the land grab literature tends to draw a picture of externally dominated, weak, or even absent states, the Tanzanian case shows that land deals with foreign investors become part and parcel of political agendas and are used to extend the reach of the local state apparatus. In both the Kisarawe and Kilolo districts, where British investors have been eager to acquire several thousand hectares for large-scale farming and forestry, district authorities have actively absorbed and used external technical and economic resources by transforming them into administrative and political tools (VLUPs, demographic data, infrastructure), thereby reasserting their power over territories and population groups. In both cases, land deals have provided space for the investors' economic interests. However, these investors' practices and decisions were reframed by state agents who, despite their limited financial and technical capacities created pockets of stateness, i.e. by reinventing administrative procedures or by requesting financial support from the investors. District authorities have turned out to play a pivotal role in land deals, acting as a nexus between central state, village, and private stakeholders. These hybrid forms of state territorialisation take place at different government levels, shaped by political and administrative agents with different, sometimes contradictory interests. Some of them form alliances with non-state actors, which can cause temporary realignments within the 
constellations of stakeholders involved in land deals. Thus, states "hosting" LSLDs are not composed of homogenous entities and unified interests, but rather of a mosaic of scales, actors, and coalitions. Land investment policies can thus be considered as a relevant research object, contributing to disciplinary debates about state sociology and state formation in Africa. As Wolford et al. have rightfully stated, "land deals are nothing more (or less) than transformations in the ground on which states are formed" (Wolford et al., 2013, p. 194).

However, this mutual interdependence between state-building and land policies is not a new phenomenon. Large-scale interventions transforming the relationship between land and population have shaped the trajectory of the Tanzanian state throughout the postcolonial era. The vijiji operation, which sought to redefine the rural landscape in order to establish a socialist society, is a prime example of state formation through land policies. After the decline of the ujamaa era, land commodification and investment-promoting policies reflected a shift from a socialist-planned economy towards a more liberal regime. Some scholars have used these policy results to assign specific attributes to the Tanzanian state, such as "post-socialist" (Fouéré, 2014; Pitcher and Askew, 2006), "development" (Green, 2014), or liberal state (Edwards, 2014; Lofchie, 2014). Instead of confirming one definition or another, the policy analysis approach reflects the multifaceted nature of the Tanzanian state (Provini and Schlimmer, 2016). Whereas the continuing adoption of investment-promoting land policies seems to reflect the successful transition from socialism to a market-led economy, their implementation in the form of LSLDs rather emphasises the predominance of complex and multi-scalar webs of state and non-state actors, who sometimes hinder or even block decision-making processes, thereby decelerating the dynamics of privatisation and liberalisation. 


\section{THE AUTHOR}

\section{Sina Schlimmer}

Sina Schlimmer is a postdoctoral research fellow at Sciences Po Bordeaux and Les Afriques dans le monde (LAM) where she is part of the FAPPA (Making Public Policies in Africa) research program. She is also an expert on peri-urban land questions at the Global Land Tool Netword and UN-Habitat in Nairobi, Kenya. In her Ph.D., she focused on the interdependence between large-scale land deals involving foreign companies in Tanzania and state-building. Her current research deals with the (non)regulation of peri-urban land markets in areas surrounding the metropolitan cities of Nairobi and Dar es Salaam.

\section{Recent publications}

Schlimmer S., 2018, "Accaparement des terres ou investissements agricoles bénéfiques? La réappropriation politique d'un problème public international en Tanzanie", Gouvernement et action publique, vol. 7, n 2, p. 31-52. DOI: 10.3917/gap.182.0031

Schlimmer S., 2018, "Les politiques foncières en Tanzanie, entre promotion de l'investissement et omniprésence de l'État. Un bilan dix ans après 'la nouvelle ruée vers les terres'", Notes de I'Ifri, May, https://www.ifri.org/fr/ publications/notes-de-lifri/politiques-foncieres-tanzanie-entre-promotion-delinvestissement (Retrieved January 2019).

Schlimmer S., 2018, "Talking 'Land Grabs' as Talking Politics: Land as A Politicised Rhetoric during Tanzanian's 2015 Elections", Journal of Eastern African Studies, vol. 12, n 1, p. 83-101. DOI: 10.1080/17531055.2017.1410757

Schlimmer S., 2017, "Starke Investoren versus schwache Staaten? Zur Komplexität öffentlichen Handelns bei Landtransaktionen am Besipiel des Agrarprojekts von Sun Biofuels in Tansania", Zeitschrift für Friedens- und Konfliktforschung, vol. 6, n 1, p. 37-72. 


\section{REFERENCES}

Abrahams R. G., 1985, Villagers, Villages and the State in Modern Tanzania, Cambridge, Cambridge African Monograph, https://www.african. cam.ac.uk/images/files/titles/villagers (Retrieved January 2019).

ActionAid, 2012, Fuel for Thought. Addressing the Social Impacts of EU Biofuel Policies, Brussels, ActionAid International, April, https://actionaid.ie/ wp-content/uploads/2016/10/Fuel-forthought-Addressing-the-social-impactsof-EU-biofuels-policies.pdf (Retrieved January 2019).

Aminzade R., 2013, Race, Nation, and Citizenship in Post-Colonial Africa. The Case of Tanzania, Cambridge, Cambridge University Press. DOI: 10.1017/CBO9781107360259

Anseeuw W., Boche M., Breu T. et al., 2013, Transnational Land Deals for Agriculture in the Global South, Bern/ Montpellier/Hamburg, CDE/CIRAD/ GIGA, p. 25, https://www.oxfam.de/ system/files/20120427_report_land_ matrix.pdf (Retrieved January 2019)

Bates R. H., 1981, Markets and States in Tropical Africa: The Political Basis of Agricultural Policies, Berkeley, University of California Press.

Bayart J.-F., 1989, L'État en Afrique. La politique du ventre, Paris, Fayard.

Bierschenk T., Olivier de Sardan J.-P., 2014, States at Work. Dynamics of African Bureaucracies, Leiden, Brill. DOI: $10.1163 / 9789004264960$
Bjerk P., 2015, Building a Peaceful Nation. Julius Nyerere and the Establishment of Sovereignty in Tanzania, 1960-1964, Rochester, University of Rochester Press.

Boesen J., Storgaard Madsen B., Moody T., 1977, Ujamaa, Socialism from Above, Uppsala, Scandinavian Institute of African Studies.

Boone C., 2014, Property and Political Order in Africa. Land Rights and the Structure of Politics, New York, Cambridge University Press.

Boone C., 2007, "Property and Constitutional Order: Land Tenure Reform and the Future of the African State", African Affairs, vol. 106, n० 425, p. 557-586. DOI: 10.1093/afraf/adm059

Boone C., Nyeme L., 2015, "Land Institutions and Political Ethnicity in Africa. Evidence from Tanzania", Journal of Comparative Politics, vol. 48, $\mathrm{n}^{\circ} 1$, p. 67-86.

Igoe J., Brockington D, 2007, “Neoliberal Conservation: A Brief Introduction", Conservation and Society, vol. 5, n० 4, p. 432-449.

Cooksey B., Kelsall T., 2011, “The Political Economy of the Investment Climate in Tanzania", Working Paper, June, London, APPP, http://www.institutions-africa.org/filestream/20121217the-political-economy-of-the-investment-climate-in-tanzania (Retrieved January 2019). 
Cotula L., 2013, The Great African Land Grab? Agricultural Investments and the Global Food System, London, Zed Books.

Cotula L, Vermeulen S., Leonard R. et al., 2009, Land Grab or Development Opportunity? Agricultural Investment and International Land Deals in Africa, London, IIED, p. 67, http://www.fao.org/3/aak241e.pdf (Retrieved January 2019).

Coulson A., 1982, Tanzania: A Political Economy, Oxford, Oxford University Press.

Dabat M.-H., 2011, “Les nouveaux investissements dans les agrocarburants. Quels enjeux pour les agricultures africaines?", Afrique contemporaine, vol. 1, n² 237, p. 97-109. DOI : 10.3917/ afco.237.0097

Darbon D., Provini O., 2018, “'Penser I'action publique' en contexts africains. Les enjeux d'une décentration", Gouvernement et action publique, vol. $7, n^{\circ} 2$, p. 9-29.

Domasa S., 2013, “Corrupt Leaders Cause Land Conflicts - Victims", The Guardian, 13 September, p. 2.

Duvail S., Médard C., Paul J.-L., 2010, “Les communautés locales face aux grands projets d'aménagement des zones humides côtières en Afrique de l'Est", Politique africaine, no 117 , p. 149-172. DOI: 10.3917/polaf.117.0149

Edwards S., 2014, Toxic Aid. Economic Collapse and Recovery in Tanzania, Oxford, Oxford University Press.
Evers S. J. T. M., Seagle C., Kritjenburg F. (ed.), 2013, Africa for Sale? Positioning the State, Land and Society in Foreign Large-Scale Land Acquisitions in Africa, Leiden, Brill, https://openaccess.leidenuniv.nl/handle/1887/37795 (Retrieved January 2019).

Fimbo G. M., 1974, "Land, Socialism and The Law in Tanzania", in Ruhumbika G. (ed.), Towards Ujamaa. Twenty Years of TANU Leadership, Nairobi, East African Literature Bureau, p. 230-274.

Fouéré M.-A., 2014, “Tanzanie: la nation à l'épreuve du post-socialisme", Politique africaine, no 121, p. 69-86. DOI: 10.3917/ polaf.121.0069

Friis-Hansen E., 1987, Changes in Land Tenure and Land Use Since Villagization and Their Impact on Peasant Agricultural Production in Tanzania, Copenhagen, Centre for Development Research.

Green M., 2014, The Development State. Aid, Culture and Civil Society in Tanzania, Woodbridge, James Currey.

Häberli C., Smith F., 2014, "Food Security and Agri-Foreign Direct Investment in Weak States: Finding the Governance Gap to Avoid Land Grab'", The Modern Law Review, vol. 77, n² 2, p. 189-222.

Hagmann T., Péclard D., 2010, “Negotiating Statehood: Dynamics of Power and Domination in Africa", Development and Change, vol. 41, n० 4, p. 539-562. DOI: 10.1111/j.1467-7660.2010.01656.x

HakiArdhi, 2013, Biofuels in Tanzania: Small Scale Producers and Sustainable Environmental Management, Dar es Salaam, HakiArdhi, https:// www.landportal.org/es/library/ resources/978-9987-626-18/biofuelstanzania-small-scale-producers-andsustainable (Retrieved January 2019). 
Hall R., Scoones I., Dzodzi T. (ed.), 2015, Africa's Land Rush: Rural Livelihoods and Agrarian Change, London, James Currey.

Harrison G., 2010, Neoliberal Africa: The Impact of Global Social Engineering, London, Zed Books.

Hassenteufel P., 2014, Sociologie politique : I'action publique, Paris, Armand Colin.

Hill M., Hupe P., 2014, Implementing Public Policy: An Introduction to the Study of Operational Governance, London, Sage.

Hyden G., 1975, "Ujamaa, Villagisation and Rural Development in Tanzania", Development Policy Review, vol. 8, $\mathrm{n}^{\circ}$ 1, p. 53-72. DOI: https://doi. org/10.1111/j.1467-7679.1975.tb00439.x

Hyden G., 1980, Beyond Ujamaa in Tanzania: Underdevelopment and An Uncaptured Peasantry, Edinburgh, Heinemann Educational Books.

Isaksson R., Sigte I., 2009, Allocation of Tanzanian Village Land to Foreign Investors. Conformity to Tanzania's Constitution and the African Charter on Human and People's Rights, Umeå, University of Umeå.

Kaag M., Zoomers A. (ed.), 2014, The Global Land Grab: Beyond the Hype, London, Zed Books.

Kamata N., 2010, "Mwalimu Nyerere's Ideas on Land", in Chachage C., Cassam A. (ed.), Africa's Liberation: The Legacy of Nyerere, Cape Town, Pambazuka Press, p. 105-119.
Kenney-Lazar M., 2012, "Plantation Rubber, Land Grabbing and SocialProperty Transformation in Southern Laos", Journal of Peasant Studies, vol. 39, no 3-4, p. 1017-1037. DOI: 10.1080/03066150.2012.674942

Kitabu G., 2013, “Dubious Land Sale in Bagamoyo Creates Dispute Between Villagers and Investor", The Guardian, 08 March, p. 3.

Klopp J.M., "Pilfering the Public. The Problem of Land Grabbing in Contempory Kenya", Africa Today, vol. 47, n 1 , p. 7-26.

Kubegeya M., 2015, "I Will Work for Your Social Security: Mghwira", The Citizen, 29 September.

Lal P., 2015, African Socialism in PostcoIonial Tanzania. Between the Village and the World, Cambridge, Cambridge University Press. DOI: 10.1017/ CB09781316221679

Lavers T., Boamah F., 2016, "The Impact of Agricultural Investments on State Capacity: A Comparative Analysis of Ethiopia and Ghana", Geoforum, n० 72, p. 94-103. DOI: 10.1016/j. geoforum.2016.02.004

Liberti S., 2013, Main basse sur la terre. Land grabbing et nouveau colonialisme, Paris, Rue de l'échiquier.

Locher M., 2017, "How Come That Others Are Selling Our Land? Customary Land Rights and the Complex Process of Land Acquisition in Tanzania", Journal of Eastern African Studies, vol. 10, n 3, p. 393-412. DOI: 10.1080/17531055.2016.1250890 
Locher M., 2015, The "Global Land Rush", Local Land Rights and Power Relations: European Forestry Investments in Tanzania, PhD thesis, University of Zürich. DOI: 10.5167/uzh-117347

Locher M., Müller-Böker U., 2014, "'Investors Are Good, If They Follow the Rules' - Power Relations and Local Perceptions in the Case of Two European Forestry Companies in Tanzania", Geographica Helvetica, n०69, p. 249-258. DOI: 10.5194/gh-69-249-2014

Locher M., Sulle E., 2014, “Challenges and Methodological Flaws in Reporting the Global Land Rush: Observations from Tanzania", Jounal of Peasant Studies, vol. 41, no 4, p. 569-592. DOI: 10.1080/03066150.2014.919263

Lofchie M., 2014, The Political Economy of Tanzania: Decline and Recovery, Philadelphia, University of Philadelphia Press. DOI: 10.1111/ehr.12119_33

Lugungulo A., 2011, “Investor Suspends Jatropha Project. Lays off 750 Workers, Yet to Pay Land Dues", The Guardian, 17 October, p. 1-2.

Lugungulo A., 2010, "UK Investor Fails to Compensate Land Owners", The Guardian, 22 February, p. 18.

Lund C., Boone C., 2013, "Introduction: Land Politics in Africa - Constituting Authority over Territory, Property and Persons", Africa, vol. 83, no 1, p. 1-13. DOI: $10.1017 /$ S000197201200068X

Manji A., 2012, "The Grabbed State. Lawyers, Politics and Public Land in Kenya", The Journal of Modern African Studies, vol. 50, n 3, p. 467-492.
Manji A., 1998, "Gender and the Politics of Land Reform Process in Tanzania", The Journal of Modern African Studies, vol. 36, n 4, p. 645-667.

Materu B., 2016, "Tough Conditions for Foreigners Eyeing Land for Business in Tanzania", The East Africain, 07 December.

McHenry D. E., 1979, Tanzania's Ujamaa Villages. The Implementation of $A$ Rural Development Strategy, Berkeley, Institute of International Studies.

Migdal J. S., Schlichte K., 2005, "Rethinking the State", in Schlichte K. (ed.), The Dynamics of States. The Formation and Crisis of State Domination, Aldershot, Ashgate, p. 1-40, https:// www.researchgate.net/publication/291962193_Rethinking_the_State (Retrieved January 2019).

Moreda T., 2017, "Large-Scale Land Acquisitions, State Authority and Indigenous Local Communities: Insights from Ethiopia", Third World Quarterly, vol. 38, n³, p. 698-716. DOI: 10.1080/01436597.2016.1191941

Nolte K., Väth J. S., 2015, “Interplay of Land Governance and Large-Scale Agricultural Investment: Evidence from Ghana and Kenya", Journal of Modern African Studies, vol. 54, n 1, p. 69-92. DOI: 10.1017/S0022278X14000688

Nyerere J. K., 1966, Freedom and Unity, London, Oxford University Press.

Nyerere J. K., 1968, Ujamaa: Essays on Socialism, Dar es Salaam, Oxford University Press. 
Pedersen R. H., 2016, "Access to Land Reconsidered: The Land Grab, Polycentric Governance and Tanzania's New Land Reform", Geoforum, no 72, p. 104-113. DOI: 10.1016/j. geoforum.2015.12.010

Pedersen R. H., 2012, “Decoupled Implementation of New-Wave Land Reforms: Decentralisation and Local Governance of Land in Tanzania", Journal of Development Studies, vol. 48, n 2, p. 268-281. DOI: 10.1080/00220388.2011.635202

Peluso N. L., Lund C., 2011, "New Frontiers of Land Control: Introduction", Journal of Peasant Studies, vol. 38, no 4, p. 667-681. DOI: 10.1080/03066150.2011.607692

Pitcher A., Askew K. M., 2006, "African Socialims and Postsocialisms", Africa: The Journal of the International African Institute, vol. 76, no 1, p. 1-14. DOI: 10.3366/afr.2006.0001

Provini O., Schlimmer S., 2016, “Négocier I'action publique dans un État sous régime d'aide : une analyse comparée des politiques de l'enseignement supérieur et du foncier en Tanzanie", Revue internationale de politique comparée, vol. 23, n² 2, p. 199-223. DOI : 10.3917/ripc.232.0199

Schlimmer S., 2018a, "Accaparement des terres ou investissements agricoles bénéfiques? La réappropriation politique d'un problème public international en Tanzanie", Gouvernement et action publique, vol. 7, $\mathrm{n}^{\circ} 2$, p. 31-52. DOI: 10.3917/gap.182.0031
Schlimmer S., 2018b, "Talking 'Land Grabs' as Talking Politics: Land as A Politicised Rhetoric during Tanzanian's 2015 Elections", Journal of Eastern African Studies, vol. 12, no 1, p. 83-101. DOI: 10.1080/17531055.2017.1410757

Schlimmer S., 2017, Construire l'État par les politiques foncières. La négociation des transactions foncières en Tanzanie, PhD thesis, Bordeaux, University of Bordeaux/Sciences Po Bordeaux, http://www.theses.fr/2017BORD0736 (Retrieved January 2019).

Schlimmer S., 2016, "Bureaucracy vs. Land Grabbing? Replacing the State in a Fashionable Debate in Tanzania", Mambo!, vol. 14, no 4, p. 1-4, https:// mambo.hypotheses.org/974 (Retrieved February 2019).

Scott J., 1998, Seeing Like A State: How Certain Schemes to Improve the Human Condition Have Failed, New Haven, Yale University Press.

Smalley R., Corbera E., 2012, “LargeScale Land Deals from the Inside Out: Findings from Kenya's Tana Delta", Journal of Peasant Studies, vol. 39, no 3-4, p. 1039-1075. DOI: 10.1080/03066150.2012.686491

Sulle E., Nelson F., 2009, Biofuels, Land Access and Rural Livelihoods in Tanzania, London, IIED, http://pubs. iied.org/pdfs/12560IIED.pdf (Retrieved January 2019).

Sun Biofuels, 2006, District Proposal. Kisarawe, Coast Province, official document, London. 
Sundet G., 2004, The Politics of Land in Tanzania, PhD thesis, Oxford, University of Oxford, https://ora.ox.ac.uk/ objects/uuid:1f73c896-4495-4aa7-89c5a7cbc69a44c4 (Retrieved January 2019).

TIC (Tanzania Investment Centre), 2017, "About us", http://www.tic.co.tz/ missionVission\# (Retrieved January 2019).

The Citizen, 2013, "Kisarawe Villagers Fight Against Lopsided Land Lease Plan", The Citizen, 11 September.

The Guardian, 2005, “Gvmt Sets Aside Land for Investment", The Guardian, 17 June, p. 1.

The Guardian, 2013, "Kisarawe Residents Set to Drag Govt to Court over Land Conflict", The Guardian, 10 September, p. 2.

The Oakland Institute, 2011, Understanding Land Investment Deals in Africa. Country Report: Tanzania, Oakland, The Oakland Institute, https://www.oaklandinstitute.org/sites/oaklandinstitute.org/ files/OI_country_report_tanzania.pdf (Retrieved January 2019).
United Republic of Tanzania, 1967, Land Acquisition Act, Dar es Salaam, URT, https://theredddesk.org/sites/default/ files/land_acquisition_act_1967_ tanzania_2.pdf (Retrieved January 2019).

United Republic of Tanzania, 2013, Tanzania's Transformation Journey. National Key Result Areas. Agriculture 2013/142015/16, Dar es Salaam, URT, http:// www.tzdpg.or.tz/fileadmin/documents/ dpg_internal/dpg_working_groups_ clusters/cluster_1/agriculture/3. Ag_BRN/Annual_report_release_-_ docs/2._BRN_brochure.pdf (Retrieved January 2019).

Wolford W., Borras Jr. S. M. , Hall R. et al., 2013, "Governing Global Land Deals: The Role of the State in the Rush for Land", Development and Change, vol. 44, no 2, p. 189-210. DOI: 10.1111/ dech.12017

Zoomers A., 2010, "The Globalisation and the Foreignisation of Space: Seven Processes Driving the Current Global Land Grab ", Journal of Peasant Studies, vol. 37, n 2, p. 429-447. DOI: 10.1080/03066151003595325 